\title{
ANALISIS PENGARUH SUKU BUNGA KREDIT, TERHADAP INVESTASI DAN PENGEMBANGAN SEKTOR BASIS DI KABUPATEN MUARO JAMBI
}

oleh :

\author{
*)Adi Putra, SP., M.E. \\ *) Arniwita S.Pd., M.M. \\ **) Dosen STIE Muhammadiyah Jambi \\ e-mail :putramm@yahoo.co.id
}

\begin{abstract}
Abstrak
Upaya peningkatan investasi sangat terkait keberadaan sektor ekonomi yang potensial yang ada di daerah sehingga untuk itu perlu upaya yang lebih untuk identifikasi sektor-sektor ekonomi unggulan daerah yang berpotensi untuk menjadi sektor basis atau sektor penunjang dalam pembangunan ekonomi. Metode penelitian dengan data sekunder, dengan analisis Location Quetient (LQ), analisis pertumbuhan dan analisis Regresi berganda. Hasil penelitian sektor basis di Kabupaten Muaro Jambi yaitu sector Pertanian, Kehutanan, Perikanan, Jasa Lainnya, Jasa Perusahaan, Industri Pengolahan, Transportasi dan Pergudangan, dan Real Estate. Sedangkan uji regresi diperoleh nilai $F$ hitung sebesar 0,322 dan nilai $F$ tabel 9,55 yang berarti variabel suku bunga kredit BI dan sektor basis secara bersama-sama berpengaruh signifikan terhadap Investasi, sedangkan secara parsial untuk koefisien regresi suku bunga didapat nilai t hitung sebesar 1,593 sementara t tabel 2,353 artinya variabel suku bunga BI mempunyai pengaruh signifikan terhadap Investasi di Kabupaten Muaro Jambi. Sedangkan sektor pertanian dari hasil uji regresi di dapat nilai $t$ hitung lebih kecil dari $t$ tabel artinya sektor pertanian berpengaruh secara signifikan terhadap perkembangan Investasi Kabupaten Muaro Jambi.
\end{abstract}

Keywords: Location Quetient, Regresi Berganda, Pertumbuhan Ekonomi

\section{PENDAHULUAN.}

Pembangunan daerah merupakan bagian integral dari pembangunan nasional.Pembangunan nasional berkaitan erat dengan pembangunan daerah, karena pelaksanaan pembangunan daerah adalah dalam rangka pelaksanaan pembangunan yang terbesar di seluruh pelosok tanah air.Selain itu juga Pemerintah daerah dalam melaksanakan pemerintahan dan pembangunan membutuhkan danayang cukup besar. Dana pembangunan tersebut selain diperoleh dari pusat juga dari pendapatan asli daerah sendiri, yang diatur dalam peraturan perundang-undangan.

Untuk mendorong peningkatan pertumbuhan ekonomi daerah.pemerintah daerah harus mendorong serta mampu menciptakan atau menjaga iklim kondusif dalam pelaksanaan pembangunan untuk mendorong masuknya investasikarena walaupun investasi bukanlah merupakan suatu keharusan utama dalam mempercepat pertumbuhan ekonomi, namun 
diyakini investasi mempunyai dampak yang cukup besar (Todaro,2003). Oleh sebab sudah menjadi suatu keharusan untuk berupaya meningkatkan nilai investasi dalam suatu perekonomian.

Upaya peningkatan investasi sangat terkait keberadaan sektor ekonomi yang potensial (memiliki prospek ekonomi), sehingga investor dapat mengambil keputusan untuk menanamkan modalnya.Efektifitas pengelolaan sektor ekonomi potensial akanmemberi dampak yang sangat besar terhadap laju pertumbuhan ekonomi, pertumbuhan dan daya serap tenaga kerja yang tinggi,

Dari data alokasi faktor potensial yang prospek untuk dikembangkan di Kabupaten Muaro Jambi terdapat pada hampir seluruh sektor ekonomi.Terutama Sektor Pertanian,Kehutanan dan Perikananselain itu kondisi Sumberdaya manusiayang mendukung. Untuk itu dalam upaya lebih mengembangkan perekonomian daerah Kabupaten Muaro Jambisangat penting adanya identifikasi sektor-sektor ekonomi yang potensial yang berpotensi menjadi sektor basis atau sektor penunjang dalam pembangunan ekonomi.

Adapun tujuan dari penelitian yang dilakukan adalah Pertama untuk mengetahui sektor- sektor ekonomi manakah yang merupakan sektor Basis di Kabupaten Muaro Jambi, Kedua untuk mengetahui perkembangan Suku Bunga Kredit Bank Indonesia Dan Investasi di Kabupaten Muaro JambiKetigaUntuk mengetahui pengaruh sektor Basis Pertanian dan Suku Bunga Kredit Bank Indonesia terhadap Investasi Kabupaten Muaro Jambi. Sedangkan manfaat dari Penelitian ini yaitu Pertama diharapkan Penelitian ini bermanfaat dalam merumuskan kebijakan dalam upaya peningkatan investasi di Kabupaten Muaro Jambi guna mengembangkan perekonomian daerah Keduadiharapkan dengan adanya penelitian dapat menjadi acuan bagi para peneliti dan akedemisi dalam memperkaya khasanah penelitian yang sudah ada.

\section{Teori Pertumbuhan Ekonomi}

Salah satu teori ekonomi terkenal yang menganalisis hubungan antara tingkat investasi dan tingkat pertumbuhan ekonomi adalah Teori Harrod-Domar.Yang mengemukakan bahwa adanya hubungan ekonomi langsung antara besarnya stok modal keseluruhan (K), dengan GNP (Y), yang di formulasikan sebagai rasio modal/output (Capital/output ratio, COR) semakin tinggi peningkatan stok modal, semakin tinggi pula output yang dihasilkan. Yang Secara sederhana, teori Harrod-Domar dapat diformulasikan sebagai berikut $\mathrm{Y} / \mathrm{Y}=\mathrm{s} / \mathrm{kDimana}$ : $\mathrm{Y} / \mathrm{Ydi}$ gambarkan dalam tingkat perubahan atau 
tingkat pertumbuhan GNP (Yaitu, presentase perubahan GNP), s adalah rasio tabungan nasional dan $\mathrm{k}$ mengambarkan rasio modal/output nasional.

\section{Teori Sektor Basis}

Model ekonomi basis (economic base made). Ide pokok model ini adalah karena adanya perbedaan sumber daya dan keadaan geografis dalam suatu negara yang menyebabkan masing-masing region (wilayah) mempunyai keuntungan lokasi (keuntungan komperatif) terhadap beberapa sektor atau jenis kegiatan produksi.Menurut Warpani (1984) dalam Budiman (2004), koefisien spesialisasi menunjukan ukuran ekonomis tidaknya kegiatan sebuah industri.

Jika besaran nilai koefisien spesialisasi <1 berarti biaya-biaya produksi yang ditanggung industri dalam menghasilkan produk belum ekonomi.Jadi spesialisasi kegiatan ekonomi penting agara hasil produksi dalam kegiatan tersebut dapat bersaing baik diluar daerah maupun diluar negri. Sedangkan untuk mengetahui suatu sektor merupakan sektor basis atau non basis dapat digunakan metode pengukuran langsung dengan survei langsung, selain itu banyak yang memakai metode pengukuran tidak langsung untuk menentukan sektor basis dalam perekonomian diantaranya adalah adanya pendekatan yang disebut dengan Location Quetient ( LQ) yang didasari oleh teori Economic Base.

Metode analisis yang digunakan untuk melihat potensi sektoral adalah indek LQ, apabila LQ suatu sektor >1 maka diartikan sebagai suatu sektor kuat dan berpotensi untuk dikembangkan dan produknya dapat di eksport ke daerah lain. Sebaliknya jika nilai LQ $<1$ menunjukan derah yang bersangkutan mempunyai kecenderungan untuk mengimpor tersebut dari daerah lain, bila $L Q=1$ memperlihatkan daerah yang bersangkutan telah mencukupi kebutuhan lokal.

\section{Teori Investasi}

Investasi merupakan salah satu komponen yang penting dalam GNP, di Indonesia, meskipun sumbangan ini masih relatif kecil, namun investasi tetap mempunyai peran yang penting di dalam permintaan agregat.Pertama, biasanya pengeluaran investasi lebih tidak setabil apabila dibandingkan dengan pengeluaran konsumsi sehingga fluktuasi investasi dapat menyebabkan terjadinya resesi.Kedua bahwa investasi sangat penting bagi pertumbuhan ekonomi serta perbaikan dalam produktivitas tenaga kerja.Pertumbuhan ekonomi sangat tergantung pada tenaga kerja dan jumlah (stock) kapital. Investasi akan 
menambah jumlah (stock) daripada kapital. Tanpa investasi maka tidak akan ada pabrik/mesin baru, dan dengan demikian tidak ada ekspansi.

Menurut Dornbush dan Fisher (2008), investasi adalah mengeluarkan yang disediakan untuk peningkatan atau mempertahankan barang-barang modal. Investasi juga dapat diartikan sebagai mobilitas sumber daya untuk menciptakan atau menambah kapasitas produksi/pendapatan di masa yang akan datang. Ini berarti pada dasarnya investasi lebih berdimensi ekonomis,terutama tertuju pada upaya perolehan benefit (manfaat) yaitu profit (keuntungan).

\section{METODE PENELITIAN.}

Metode Penelitian yang digunakan yaitu penelitian kuantitatif, dengan data sekunder.Berupa PDRB Kabupaten MuaroJambi, PDRB Provinsi Jambi, Rencana dan realisasi investasi Di Kabupaten Muaro Jambi, Suku bunga kreditBank Indonesia dan data yang ada bersumber dari Badan Pusat Statistik, Bapemproda Kabupaten Muaro Jambi dan Bank Indonesia. Yang kemudian data tersebut diolah dengan menggunakan regresi dengan alat bantu program SPSS.

Model Analisis datauntuk menganalisis sektor mana yang merupakan sektor basis maka digunakan model analisis Location Quetient (LQ).

$$
\begin{aligned}
\text { Keterangan : } & \multicolumn{1}{c}{=\frac{y i / y t}{Y i / Y t}} \\
\text { LQ }= & \text { koefisien LQ } \\
\text { yi }= & \text { Pendapatan (PDRB) sektor I di Kabupaten Muaro Jambi } \\
\text { yt }= & \text { Pendapatan (PDRB) total Kabupaten Muaro Jambi } \\
\mathrm{Yi}= & \text { Pendapatan PDRB Provinsi Jambi menurut sektor } \\
\mathrm{Yt}= & \text { Pendapatan (PDRB) TotalProvinsi Jambi }
\end{aligned}
$$

Koefisien LQ yang dihasilkan memberikan indikasi :

- Bila LQ > 1 : sektor I memiliki tingkat spesialisasi yang berlebihan/ berpotensi ekspor inter daerah (sektor basis)

- Bila LQ = 1 : sektor I memiliki tingkat spesialisasi yang cukup ( kondisi seimbang)

- Bila LQ <1 : sektor I kurang memiliki tingkat spesialisasi/ berpotensi impor inter daerah (sektor non basis)

Kedua untuk menjawab permasalahan kedua, yaitu rumus pertumbuhan

Dimana

$$
\mathrm{x}_{n}=\frac{X_{n}-X_{n-1}}{X_{n}} \mathrm{x} 100
$$

$$
\begin{aligned}
& \mathrm{X}_{n}=\text { laju Pertumbuhan tahun } \mathrm{n} \\
& \mathrm{X}_{n}=\text { tahun tertentu } \\
& \mathrm{X}_{n-1}=\text { tahun sebelumnya }
\end{aligned}
$$


Sedangkan untuk menjawab permasalahan ketiga di gunakan rumus Regresi linier berganda, Regresi Linier Berganda adalah analisis regresi yang menjelaskan hubungan antara peubah respon (variabel dependen) dengan faktor-faktor yang mempengaruhi lebih dari satu prediktor (variabel independen).

Regresi linier berganda hampir sama dengan regresi linier sederhana, hanya saja pada regresi linier berganda variabel bebasnya lebih dari satu variabel penduga. Tujuan analisis regresi linier berganda adalah untuk mengukur intensitas hubungan antara dua variabel atau lebih dan membuat prediksi perkiraan nilai $\mathrm{Y}$ atas $\mathrm{X}$

Secara umum model regresi linier berganda untuk populasi adalah sebagai berikut:

Di mana :

$\log Y_{t}=\beta_{0_{t}}+\log \beta_{1} X_{1_{t}}+\log \beta_{2} X_{2_{t}}+\varepsilon_{t}$

$$
\begin{array}{ll}
\mathrm{Y} & =\text { Investasi (Juta Rupiah) } \\
\beta_{0} & =\text { Konstanta } \\
\beta_{1}-\beta_{3} & =\text { Koefisien Variable } \\
X_{1} & =\text { Suku Bunga Kredit (Persen) } \\
X_{2} & =\text { Sektor Basis Pertanian (Juta Rupiah) } \\
\varepsilon & =\text { Standar Error } \\
\mathrm{t} & =\text { Waktu }
\end{array}
$$

Yang selanjutnya dilanjutkan dengan Uji Hipotesis F-test ; dan uji T- dan Uji Koefisien DeterminasiKoefisien determinasi $\left(\mathrm{R}^{2}\right)$

\section{HASIL DAN PEMBAHASAN}

\subsection{Analisis Sektor Ekonomi Basis Kabupaten Muaro Jambi}

Sektor ekonomi basis merupakan gambaran dari sektor ekonomi yang mempunyai peranan yang sangat dominan dalam perekonomian suatu wilayah atau dengan kata lain merupakan sektor yang menjadi andalan dalam perekonomian wilayah.

Setelah analisis dengan metode LQ tersebut maka dapat terlihat bahwa dari tahun 2010-2015 sektor yang menjadi sektor basisdi Kabupaten Muaro Jambi seperti pada tabel 4.1 berikut ini

Tabel 4.1. Nilai Location Quetion sektoral dengan indikator PDRB Kabupaten Muaro Jambi tahun 2010-2015

\begin{tabular}{|l|c|c|c|c|c|c|c|}
\hline \multicolumn{1}{|c|}{ Sektor } & 2010 & 2011 & 2012 & 2013 & 2014 & 2015 & Rata-rata \\
\hline Pertanian,Kehutanan dan Perikanan & 1,54 & 1,57 & 1,57 & 1,58 & 1,57 & 1,57 & 1,56 \\
\hline Pertambangan dan Penggalian & 0,52 & 0,53 & 0,55 & 0,55 & 0,54 & 0,53 & 0,53 \\
\hline Industry Pengolahan & 1,48 & 1,48 & 1,48 & 1,48 & 1,50 & 1,54 & 1,24 \\
\hline Pengadaan Listrik dan Gas & 0,82 & 0,79 & 0,77 & 0,72 & 0,69 & 0,67 & 0,74 \\
\hline $\begin{array}{l}\text { Pengadaan Air, Pengelolaan Sampah, Limbah dan Daur } \\
\text { Ulang }\end{array}$ & 0,74 & 0,72 & 0,72 & 0,71 & 0,70 & 0,69 & 0,71 \\
\hline Konstruksi & 0,63 & 0,55 & 0,78 & 0,74 & 0,73 & 0,75 & 0,69 \\
\hline
\end{tabular}




\begin{tabular}{|l|c|c|c|c|c|c|c|}
\hline $\begin{array}{l}\text { Perdagangan Besar dan Eceran, Reparasi Mobil dan Sepeda } \\
\text { Motor }\end{array}$ & 0,06 & 0,56 & 0,55 & 0,53 & 0,52 & 0,50 & 0,45 \\
\hline Transportasi dan Pergudangan & 0,80 & 1,20 & 1,18 & 1,16 & 1,15 & 1,13 & 1,10 \\
\hline Penyediaan Akomodasi dan Makan Minum & 1,74 & 0,61 & 0,61 & 0,62 & 0,59 & 0,58 & 0,79 \\
\hline Informasi dan Komunikasi & 0,41 & 0,73 & 0,72 & 0,72 & 0,71 & 0,69 & 0,66 \\
\hline Jasa Keuangan dan Asuransi & 0,69 & 0,80 & 0,77 & 0,75 & 0,76 & 0,76 & 0,75 \\
\hline Real Estate & 1,99 & 0,94 & 0,83 & 0,85 & 0,85 & 0,83 & 1,03 \\
\hline Jasa Perusahaan & 1,75 & 1,15 & 1,15 & 1,15 & 1,17 & 1,14 & 1,25 \\
\hline $\begin{array}{l}\text { Administrasi Pemeintahan, Pertahanan dan Jaminan Sosial } \\
\text { Wajib }\end{array}$ & 0,24 & 0,90 & 0,90 & 0,93 & 0,92 & 0,90 & 0,79 \\
\hline Jasa Pendidikan & 0,43 & 0,58 & 0,57 & 0,58 & 0,57 & 0,55 & 0,54 \\
\hline Jasa Kesehatan dan Kegiatan Sosial & 0,90 & 0,91 & 0,89 & 0,89 & 0,89 & 0,87 & 0,74 \\
\hline Jasa Lainnya & 1,47 & 1,49 & 1,43 & 1,44 & 1,41 & 1,36 & 1,43 \\
\hline
\end{tabular}

Sumber : Kabupaten Muaro Jambi Dalam Angka, Data diolah.

Berdasarkan hasil perhitungan Location Quetion diatas menunjukan bahwa yang menjadi sektor basis di Kabupaten Muaro Jambi ada enam sektor, yaitu sektor pertanian,kehutanan dan perikanan, jasa lainnya, sektor jasa perusahaan, sektor industri pengolahan, transportasi dan pergudangan,real estate. Sedangkan sisanya adalah sektor non basis.

Sektor pertanian dalam kurun waktu 2010-2015 selalu menjadi sektor basis dalam perekonomian di Kabupaten Muaro Jambi, hal ini dapat dilihat dari tahun 2010 hasil perhitungan LQ sektor pertanian 1,54(LQ>1) terus menjadi sektor basis sampai dengan tahun 2015 yang mencapai 1,57 (LQ>1) dengan rata-rata perhitungan LQ 1,56 dan merupakan sektor basis terbesar.

Untuk sektor jasa lainnya secara rata-rata juga merupakan sektor basis dengan hasil perhitungan LQ 1,43. Sektor industri pengolahan merupakan sektor basis dimana secara rata-rata hasil perhitungan menunjukan LQ 1,24dengan angka relatif stabil. Sektor transportasi dan pergudangan relatif tidak stabil hanya pada tahun 2011-2015 yang merupakan sektor basis sedangkan untuk tahun 2010 tidak menjadi sektor basis namun sacara rata-rata sektor ini masuk dalam sektor basis karena LQ nya sebesar 1,10.

Sektor real astate merupakan sektor basis hal ini dapat dilihat dalam tahun 2010 menjadi sektor basis dalam perekonomian Kabupaten Muaro Jambi, yaitu pada tahun 2010 dengan LQ sebesar 1,99 dan itu merupakan tingkat LQ yang paling tertinggi dalam Kabupaten Muaro Jambi untuk kurun waktu 2010-2015, namun setelah itu sektor real estate tidak menjadi sektor basis lagi, namun secara rata-rata selama kurun waktu 20102015 real estate merupakan sektor basis karena nilai rata-ratanya 1,03. 
Dengan demikian keenam sektor yang menjadi basis dalam perekonomian di Kabupaten Muaro Jambi yaitu sektor pertanian,kehutanan dan perikanan, sektor jasa lainnya, sektor jasa perusahaan, industri pengolahan,transportasi dan pergudangan,real estate, memberikan gambaran bahwa keenam sektor ini memberikan kontribusi yang dominan dalam pembentukan PDRB Kabupaten Muaro Jambi, atau dengan kata lain enam sektor ini menjadi tulang punggung perekonomian Kabupaten Muaro Jambi dalam enam tahun terakhir, namun untuk sektor real estate relatif tidak stabil karena lima tahun terakhir bukan menjadi sektor basis.

\subsection{Perkembangan Suku Bunga Kredit BI Dan Investasi}

Suku Bunga Kredit BI dan Investasi merupakan komponen pokok dalam kegiatan ekonomi, dua komponen tersebut dapat membuat kegiatan perekonomian bisa maju maupun mundur, banyak jumlah investasi di suatu daerah, menandakan suku Bunga kredit yang ditetapkan pemerintah tersebut dipandang layak untuk menjalankan kegiatan ekonomi.

Dengan tingkat suku bunga yang sesuai maka penanam modal, baik PMDN maupun PMA untuk berinvestasi di kabupaten Muaro Jambi juga akan meningkat. Untuk melihat perkembangan Suku Bunga dan Investasi di Kabupaten Muaro Jambi seperti pada table 4.2. di bawah ini.

Tabel 4.2 Perkembangan Suku Bunga dan Investasi Kabupaten Muaro Jambi 2010-2015

\begin{tabular}{|c|c|c|c|}
\hline Tahun & Suku Bunga Kredit(\%) & Investasi (Juta Rupiah) & Perkembangan(\%) \\
\hline 2010 & 6,50 & 822067.87 & - \\
\hline 2011 & 6,75 & 898059.95 & 9.24 \\
\hline 2012 & 6,00 & 820787.22 & -8.60 \\
\hline 2013 & 7,50 & 900320.44 & 9.68 \\
\hline 2014 & 7,75 & 902420.25 & 2.33 \\
\hline 2015 & 7,50 & 904500.24 & 2.30 \\
\hline \multicolumn{2}{|c|}{} \\
\hline
\end{tabular}

Sumber : BPS Muaro Jambi 2016

Berdasarkan tabel diatas dapat kita lihat bahwa tingkat suku bunga kredit BI dari tahun 2010-2015 selalu mengalami kenaikan, kenaikan suku bunga kredit dalam kegiatan ekonomi adalah hal yang sering terjadi dan tidak terlalu menjadi sebuah dilema yang harus di khawatirkan.

Sedangkan dari kegiatan investasi yang terjadi di Kabupaten Muaro Jambi bisa kita lihat bahwa kegiatan investasi di Kabupaten Muaro Jambi cenderung selalu mengalami peningkatan, namun di tahun 2012 investasi di Kabupaten Muaro Jambi 
Mengalami penurunan, penurunan tersebut relatif cukup besar yaitu $-8.60 \%$, namun secara keseluruhan dari tahun 2010-2015 kegiatan investasi di Kabupaten Muaro Jambi mengalami perkembangan sebesar $2.49 \%$ setiap tahunnya.

\subsection{Analisis Pengaruh Sektor Basis Pertanian, Suku Bunga Kredit BI Terhadap Investasi di Kabupaten Muaro Jambi}

Hubungan empiris antara faktor-faktor yang mempengaruhi realisasi suku bunga kredit pada sektor basis terpilih di Kabupaten Muaro Jambi dalam periode 2010-2015 diperoleh dengan menggunakan bantuan program SPSS, menerapkan metode regresi berganda. Sebagai variabel dependent adalah total investasi, sedangkan variabel independent adalah suku bunga kredit dan sektor pertanian.

Berdasarkan perhitungan tersebut maka diperoleh hasil regresi pengaruh sektor pertanian dan tingkat suku bunga kredit BI terhadap investasi di Kabupaten Muaro Jambi didapat persamaan regresi sebagai berikut :

$$
\begin{aligned}
\log \mathrm{Y} & =624.327+49.230 X_{1}+4.343 X_{2} \\
& =(171.479)(30.913)(8.121) \text { Standar Error } \\
& =(3.641)(1.593)(535) \mathrm{t} \text { hitung } \\
\mathrm{F} \quad & =0.322 \\
\mathrm{R} \quad & =0.884 \\
R^{2} & =0,768
\end{aligned}
$$

Dari hasil regresi berganda diperoleh konstanta sebesar 624.327, artinya jika suku bunga kredit BI dan sektor basis pertanian sama dengan nol, maka realisasi investasi yang terjadi naik sebesar 624.327, dan setiap kenaikan 1 persen dari suku bunga kredit BI maka akan menaikan realisasi investasi sebesar Rp 49.230, sedangkan bila terjadi kenaikan 1 persen dari sektor basis pertanian, maka akan menaikan realisasi investasi sebesar Rp 4.343

Nilai R sebesar 0,884 menunjukan hubungan yang kuat antara variabel yang dipengaruhi (Investasi) dengan variabel yang mempengaruhi (suku bunga kredit dan sektor basis). Sedangkan nilai $\mathrm{R}^{2}$ sebesar 0,768 menunjukan bahwa76,8 persen perubahan yang terjadi pada realisasi investasi dijelaskan oleh perubahan yang terjadi pada suku bunga kredit dan sektor pertanian. Sedangkan sisanya 23.2 persen dijelaskan oleh faktor-faktor lain diluar model tersebut.

Dari nilai yang didapat berupa $\mathrm{F}$ hitung yaitu 0,322 , sedangkan nilai $\mathrm{F}$ tabel dapat diperoleh dengan menggunakan tabel F dengan derajat bebas (df) Residual (sisa) 
yaitu 3 sebagai df penyebut dan df Regression (perlakuan) yaitu 2 sebagai df pembilang dengan tarap siginifikan 0,05 , sehingga diperoleh nilai $F$ tabel yaitu 9,55 . Karena $F$ hitung $(0,322)<\mathrm{F}$ tabel $(9.55)$ maka Ho diterima.

juga berdasarkan data diatas, dapat dilihat bahwa nilai thitung untuk Suku bunga yaitu 1.593, pada t tabel dengan db 12 dan taraf signifikan 0,05 diperoleh 2,353, karena $t$ hitung $<\mathrm{t}$ tabel maka Ho diterima. sedangkan sig pada tabel $\mathrm{B}$ adalah 0,03 yang berarti probabilitas 0,03 , karena probabilitas kurang dari 0,05 maka diterima. artinya B tidak berarti.

Berdasarkan tabel diatas, dapat dilihat bahwa nilai t hitung untuk sektor basis yaitu 0,535 , pada t tabel dengan db 12 dan taraf signifikan 0,05 diperoleh 2,353, karena $t$ hitung $<\mathrm{t}$ tabel maka Ho diterima. sedangkan sig pada tabel $\mathrm{B}$ adalah 0,02 yang berarti probabilitas 0,02 , karena probabilitas kurang dari 0,05 maka diterima. artinya B tidak berarti

\subsection{Implikasi Kebijakan Ekonomi}

Pemerintah merupakan pihak yang berkompoten dalam mengatur dan menggerakan serta mengerahkan perekonomian suatu daerah. Berdasarkan temuan empiris, maka upaya dalam meningkatkan pertumbuhan ekonomi daerah, pemerintah diharapkan bisa menerapkan kebijakan sebagai berikut:

1. Pemerintah perlu mendukung pembangunan sektor pertanian dengan tidak mengesampingkan sektor lainnya, seperti halnya perbaikan atau penambahan infrastruktur dan faktor pendukung lainnya.

2. Pemerintah bersama masyarakat diharapkan mampu menciptakan kestabilan nasional guna mendorong minat investor untuk berinvestasi serta di dorong kebijakankebijakan yang mendukung investasi lainnya.

3. Pemerintah diharapkan mampu menciptakan sumber daya manusia yang lebih baik guna mendorong investor untuk berinvestasi sehingga produktivitas tenaga kerja menjadi lebih baik.

\section{KESIMPULAN}

\subsection{Adapun Kesimpulan yang dapat dirumuskan dalam penelitian ini yaitu :}

1. Hasil perhitungan Location Quetion menunjukan sektor basis di Kabupaten Muaro Jambiyaitu sektor Pertanian, Kehutanan, Perikanan, Jasa Lainnya, Jasa Perusahaan, 
Industri Pengolahan, Transportasi dan Pergudangan, dan Real Estate, sedangkan yang lainnya bukan merupakan sektor basis.

2. Secara simultan diperoleh nilai $F$ hitung sebesar 0,322 dan nilai $F$ tabel 9,55 yang berarti bahwa F hitung lebih kecil dari F tabel. Hal ini dapat diartikan bahwa variabel suku bunga kredit BI dan sektor basis secara bersama-sama berpengaruh signifikan terhadap Investasi di Kabupaten Muaro Jambi.

3. Secara parsial untuk koefisien regresi suku bunga didapat nilai t hitung sebesar 1,593 sementara $\mathrm{t}$ tabel 2,353 artinya variabel suku bunga BI mempunyai pengaruh signifikan terhadap Investasi di Kabupaten Muaro Jambi. Sedangkan sektor pertaniandari hasil uji regresi di dapat nilai t hitung lebih kecil dari t tabel artinya sektor pertanianberpengaruh secara signifikan terhadapperkembangan Investasi Kabupaten Muaro Jambi.

\subsection{Sedangkan saranyang didapat setelah dilakukan penelitian ini yaitu}

1. Pemerintah Kabupaten Muaro Jambi diharapkan mampu melihat peluang yang bisa di dapatkan dari sektor basis dan dapat menentukan kebijakan perekonomian dalam menumbuhkan sektor pertanian yang merupakan sektor potensial di Kabupaten Muaro Jambi

2. Pemerintah Kabupaten Muaro Jambi beserta masyarakat harus bersama-sama menciptakan kestabilan disegala aspek guna meningkatkan minat investor untuk berinvestasi di Kabupaten Muaro Jambi

\section{DAFTAR PUSTAKA}

Anonim , 2008, Jambi Dalam Angka, BPS, Provinsi Jambi

2008, Rencana Dan Realisasi PMDN Dan PMA Provinsi Jambi Bapemproda Provinsi Jambi

2008, Statistik Ekonomi Keuangan daerah dan Indonesia, Bank Indonesia

Arsyad,Lyncolin. 2002. Transformasi Struktur Ketenagakerjaan Dan Pertumbuhan Ekonomi. Gramedia Jakarta

Alam M. Rugman. Et. Al Internasional Business. Firm And Environment, New York. MC. Graw Hill Book. 2006

Budiman,2010, Ekonomi Perencanaan, BPFE-UI, Jakarta 
Dornbusch , 2008, Makroekonomi, PT. Media Global Edukasi. Jakarta

Glasson, 2007, Ekonomi Pembangunan, Gramedia, Jakarta

Gujarati, Damodar. 2003. Ekonometrika Rajawali Pres. Jakarta

Ismawan,2008, Teori Ekonomi Mikro, Rajawali Press,Jakarta

Kadariah. 2008. Ekonomi Perencanaan, LPFE - UI, Jakarta

Krugman, Paul. R dan Obstfeld, Maurice, 2001. Ekonomi Internasional : Teori dan Kebijakan. Rajawali Press. Jakarta

Martiono.2000. pola Industri dan Teknologi. Makalah Seminar : ISEI, Bandung

Nasution , Anwar, 2007. Perkembangan Perekonomian Indonesia dan Dampak Jangka Pendek Serta Implikasi Jangka Panjang.Prisma. Jakarta

Obstfield,2001, Mikro Ekonomi, Rajawali Press, Jakarta

Rugman, 2001, Statik Ekonomi, Erlangga, Jakarta

Sidik,2004, Ekonomi Pembangunan, Erlangga, Jakarta

Soeparmoko, M, 2001, Pengantar Ekonomi Makro, BPFE, Yogyakarta

Soeparmoko ,2009, Ekonomika Pembangunan, BP FE - UGM, Yogyakarta

Sukirno, Sadono, 2001, Pengantar Teori Makro Ekonomi, Edisi II, Raja Grafindo Persada, Jakarta

Syafrizal, 2006, Teori Ekonomi Mikro, Grafindo Persada, Jakarta

Syahrir , 2004, Spektrum Ekonomi Politik Indonesia. LPFE - UI, Jakarta

Todaro, MP, 2003. Pembangunan Ekonomi di Dunia Ketiga, PT Gelora Aksara Pratama, Jakarta. 